\title{
An Empirical Investigation into Examination of Factors Influencing University Students' Behavior towards E- learning Acceptance Using SEM Approach
}

\author{
https://doi.org/10.3991/ijim.v14i02.11115 \\ Barween Al Kurdi \\ Amman Arab University, Amman, Jordan \\ Muhammad Alshurideh \\ University of Sharjah, Sharjah, UAE \\ The University of Jordan, Amman, Jordan \\ Said A. Salloum ${ }^{(凶)}$ \\ University of Sharjah, Sharjah, UAE. \\ The British University in Dubai, Dubai, UAE \\ ssalloumesharjah.ac.ae \\ Zaid Mohammad Obeidat, Rami Mohammad Al-dweeri \\ The University of Jordan, Amman, Jordan
}

\begin{abstract}
There are several reasons why most of the universities implement E-learning. The extent of E-learning programs is being offered by the higher educational institutes in the UAE are evidently expanding. However, very few studies have been carried out to validate the process of how E-learning is being accepted and employed by university students. The study involved a sample of 365 university students. To describe the acceptance process, the Structural Equation Modeling (SEM) method was used. On the basis of the technology acceptance model (TAM), the standard structural model that involved E-learning Computer Self-Efficacy, Social Influence, Enjoyment, System Interactivity, Computer Anxiety, Technical support, Perceived Usefulness, Perceived Ease of Use, Attitude, and Behavioral Intention to Use e-learning, was developed. The findings showed that TAM served as a suitable theoretical tool to comprehend the acceptance of e-learning by users. The most critical construct to explain the causal process employed in the model was E-learning Computer Self-Efficacy, Social Influence, Enjoyment, System Interactivity, Computer Anxiety, Technical support, Perceived Usefulness, Perceived Ease of Use, Attitude, followed by Behavioral Intention to Use e-learning. Practical implications are offered by the outcomes for decision makers, professionals and developers in how effective E-learning systems can be implemented properly.
\end{abstract}

Keywords-University students, Technology Acceptance Model (TAM), Computer Self-Efficacy, Social Influence, Enjoyment, System Interactivity, Computer Anxiety, Technical support, Perceived Usefulness, Perceived Ease of 
Use, Student's intention to use E-learning, The structural equation modeling (SEM), United Arab Emirates.

\section{$1 \quad$ Introduction}

Various opportunities and inventions have emerged within the learning environment of the UAE universities because of the speedy developments in information technology. A Web-based learning platform that has a practical and more flexible framework for supporting both teachers and learners is offered by E-learning. Through E-learning, knowledge can be shared with an extensive audience using various tools and systems like Internet, email, discussion groups, Intranet, chat, blogs, wikis, etc. [1]. Different services are offered by E-learning which can be modified in accordance with the requirements, knowledge, competency and experience of the students [2]. E-learning has been incorporated into the university education system in the UAE to provide greater access to higher education and to enhance the quality of learning offered in universities. E-learning can be considered as a good mean that facilitate the delivering process of teaching and learning. There are various advantages of E-learning to the university students as compared to conventional learning systems. For example, there are a set of place, time and people limitations in the conventional learning systems use, whereas such limitations cannot be found when employing E-learning as it can be used at any place and at any time.

E-learning system is linked to technology; hence, it is important for developers and deliverers to comprehend the way users consider and respond to the E-learning systems. This will offer them an improved understanding of the way E-learning approach can be developed and offered to the users in an effective and efficient manner so as to enhance the learning experience. Even though E-learning systems are being developed within several universities in the UAE, the success of these systems would be determined by the acceptance shown by the university students who are heavily involved in such systems. There are two levels at which adoption to technology could be examined, i.e. at both the organizational and individual levels. This study concentrated on the individual level; hence, the emphasis was on university students who were presently involved in using the E-learning system as part of their routine learning process. To achieve this, the basis of the research model of this study was the Technology Acceptance Model (TAM)[3], which is the model used most extensively to justify the technology acceptance behavior of users [4]. In various studies carried out on the users' perceived acceptance of any technology, TAM was employed to justify the theoretical part of the model. In this study, TAM was taken to be the base model, along with a few integrated factors, so that the attitude pertaining to the actual use of E-learning and the behavior intention to use it could be investigated.

\section{$2 \quad$ Literature Review}

Various studies are part of the research on E-learning which examine how certain students' attributes influence their acceptance and use of online technology. The rea- 
sons why students prefer an online delivery system could include their perceived ease of use that would be exhibited from their skills they possess regarding their use of the internet and electronic communication, as well as their capacity to be involved in independent learning. The perspective of an individual regarding the usefulness of an online learning is another attribute that may enhance their academic success within an online setting [5]. In addition, other factors linked to individual attributes include the social influence of students' referent groups and students' outlook with respect to online learning, and these may influence their preference for online learning [6]-[8]. The actual usage of the technology by the users is affected to a large extent by their behavioral intention, which is affected by their previous experience of using such technology [9]-[12]. A comprehensive theoretical framework of E-learning acceptance and intention to use of university students is put forward in this study is based to a large extent on the TAM [13]. The study aimed to assess the way by which the intention to use E-learning of university students was related to specific constructs like "Computer Self-Efficacy", "Social Influence”, "Enjoyment”, "System Interactivity", "Computer Anxiety", and "Technical support", to formulate a general linear structural model of E-learning acceptance of university students which would offer implications improvement for school managers or educators to implement E-learning systems. Certain descriptive features of the use of E-learning and the chosen constructs were also identified.

\section{$3 \quad$ Research Model and Hypotheses}

A conceptual model of E-learning technology acceptance on the basis TAM is put forward and assessed in this paper, using previous literature that employed TAM in the context of education. The model also presents an extension of TAM by adding further predictor variables of "Computer Self-Efficacy", "Social Influence", "Enjoyment", "System Interactivity", "Computer Anxiety", and "Technical support". Figure 1 presents the complete conceptual model and the following sections describe and explain every one of the predicted relationships, keeping in view the previous results from the literature.

\subsection{Computer self-efficacy (CSE)}

According to [14]-[16], self-efficacy is "the degree to which an individual believes that he or she has the ability to perform a specific task/job using the computer". It was revealed in prior e-learning research that there is a significant impact of CSE on perceived usefulness (PU) [17]-[28]. Previous research also triggered out that there is a significant relationship between CSE and the perceived ease of use (PEOU) of elearning [18], [22], [23], [25], [29]-[35]. Hence, we hypothesize the following:

H1a: Computer self-efficacy (CSE) has a positive effect on the perceived usefulness (PU) of the e-learning system.

H1b: Computer self-efficacy (CSE) has a positive effect on the perceived ease of use (PEOU) of the e-learning system. 


\subsection{Social influence (SI)}

The social influence refers to "the degree to which an individual perceives that most people who are important to him think he should or should not use the system" [36]-[39]. It has been shown in numerous studies conducted earlier that social influence (SI) has a significant association with PU [7], [40]-[42]. Furthermore, social influence (SI) can have a stronger impact on perceived ease of use (PEOU) of elearning [7], [34]. Hence, the following hypotheses are suggested:

H2a: Social influence (SI) will have a positive effect on perceived usefulness (PU).

H2b: Social influence (SI) will have a positive effect on perceived ease of use (PEOU).

\subsection{Enjoyment (ENJ)}

Enjoyment (ENJ) is defined by [43] as "the extent to which the activity of using a specific system is perceived to be enjoyable in its own right, aside from any performance consequences resulting from system use" [44]. Previous research indicated that enjoyment (ENJ) has a significant relationship with perceived usefulness (PU) [20], [29], [33], [45]. It was also pointed out that enjoyment (ENJ) is significantly affecting the perceived ease of use (PEOU) of e-learning [20], [27], [28], [40], [42], [46] Therefore, the following hypotheses are put forward:

H3a: Enjoyment (ENJ) has a positive effect on the perceived usefulness (PU) of elearning system.

H3b: Enjoyment (ENJ) has a positive effect on the perceived ease of use (PEOU) of e-learning system.

\subsection{System interactivity (SIN)}

System Interactivity (SIN) refers to "the interactions between faculty and students, and the collaboration in learning that results from these interactions" [30]. In previous e-learning research, system interactivity (SIN) is found to have a significant impact on perceived usefulness (PU) [30], [41], [46]-[49]. Also, previous e-learning studies pointed out that system interactivity (SIN) has a significant effect on perceived ease of use (PEOU) [30], [41], [46]-[49]. Thus, the following hypothesis is put forward:

H4a: System Interactivity (SIN) has a positive effect on the perceived usefulness (PU) of e-learning system.

H4b: System Interactivity (SIN) has a positive effect on the perceived ease of use (PEOU) of e-learning system.

\subsection{Computer anxiety (CA)}

Computer anxiety (ANX) is defined as "an individual's apprehension or even fear, when she/he is faced with the possibility of using computers" [44]. Moreover, [50] defines that computer anxiety as "the tendency of a person to experience a level of uneasiness over his or her impending use of a computer" (page number). It has been 
indicated in previous studies that computer anxiety (CA) has a direct and significant impact on the perceived usefulness (PU) [20], [27], [29], [42], [51]-[53]. Some previous studies indicated that computer anxiety (CA) has a direct and significant impact on the perceived ease of use (PEOU) [20], [27], [29], [42], [51]-[54] . Therefore, the following hypothesis is suggested:

H5a: Computer Anxiety (CA) has a positive effect on the perceived usefulness (PU) of e-learning system.

H5b: Computer Anxiety (CA) has a positive effect on the perceived ease of use (PEOU) of e-learning system.

\subsection{Technical support (TS)}

Technical support can be defined as "people assisting the users of computer hardware and software products, which can include hotlines, online support service, machine-readable support knowledge bases, faxes, automated telephone voice response systems, remote control software and other facilities" [55]. Several e-learning studies triggered out that technical support (TS) has a significant impact on perceived usefulness (PU) [30], [31], [56]. To add more, Some previous studies found that e-learning studies pointed out that technical support (TS) has a significant association with the perceived ease of use (PEOU) [31], [56]. Hence, the following hypothesis is formulated:

H6a: Technical support (TS) has a positive effect on the perceived usefulness (PU) of e-learning system.

H6b: Technical support (TS) has a positive effect on the perceived ease of use (PEOU) of e-learning system

\subsection{Core TAM constructs}

The adoption of new technology is facilitated by the perceived usefulness and perceived ease of use factors. It was explained earlier that in TAM and other relevant studies, these factors have a significant impact on the behavioral intention to use. The perspective of the user regarding the ease of understanding has a significant impact on determining the effectiveness and the extent to which user's adapt to the new technology [4], [57]. The significant influence of perceived ease of use (PEOU) on perceived usefulness (PU) is shown in a previous research. In the past, several studies were carried out, which showed that there is a positive correlation between the perceived ease of use (PEOU) and the behavioral intention to use E-learning (BI), and this relationship is direct as well as indirect [1], [7], [17], [18], [27], [32], [34], [43], [46], [56], [58]-[61]. Moreover, there is strong empirical support for the correlation between PU and the attitude towards the use in the previous studies [17], [24], [32], [40], [43], [56], [62]-[67]. In addition, previous research indicated that there is positive relation between PEOU and the attitudes toward the use of e-learning system (ATT) [17], [32], [40], [43], [56], [64]-[66]. Previously, several studies have been conducted which declare that the perceived ease of use (PEOU) has a positive relationship with the behavioral intention to use E-learning system (BI), both direct and 
indirect [7], [34], [43], [60], [68]-[70]. According to [71], users' intention to directly or indirectly agree to and adapt to the E-learning system will be impacted by the perceived usefulness (PU). A significant positive association between perceived usefulness (PU) and the intention to use the E-learning system (BI) is also proofed by the following studies [1], [17], [21], [32], [46], [58]-[60], [69]. To add more, It has been shown by the following studies [1], [7], [17], [32], [34], [43], [64], [72], [73] that attitude (ATT) has a direct impact on behavioral intention (BI). Hence, to determine the way the attitude of students affects their acceptance and use of e-learning system, some studies in e-learning pointed out that behavioral intention to use (BI) directly and significantly influences the actual system use (AU) of e-learning [22], [30], [34], [42], [46], [67], [74]-[76]. Accordingly, this research banks on the presumption of the hypotheses given below, as obtained from the previous literature, while depicting a significant positive relationship between PU, PEOU, ATT, BI and AU.

H7: Perceived ease of use (PEOU) has a positive effect on the Perceived usefulness (PU) of the e-learning system.

H8: Perceived ease of use (PEOU) has a positive effect on attitude towards the use (ATT) of e-learning system.

H9: Perceived usefulness (PU) has a positive effect on the attitude towards the use (ATT) of the e-learning system.

H10: Perceived ease of use (PEOU) has a positive effect on the behavioral intention (BI) to use the e-learning system.

H11: Perceived usefulness (PU) has a positive effect on the behavioral intention (BI) to use the e-learning system.

H12: Attitude towards use (ATT) has a positive effect on the behavioral intention (BI) to use the e-learning system.

H13: The behavioral intention to use (BI) has a positive effect on the actual use (AU) of e-learning system.

The research model (Figure 2) shown below is developed from the hypotheses given above, keeping in view the extended TAM model for E-learning adoption or acceptance by students. 


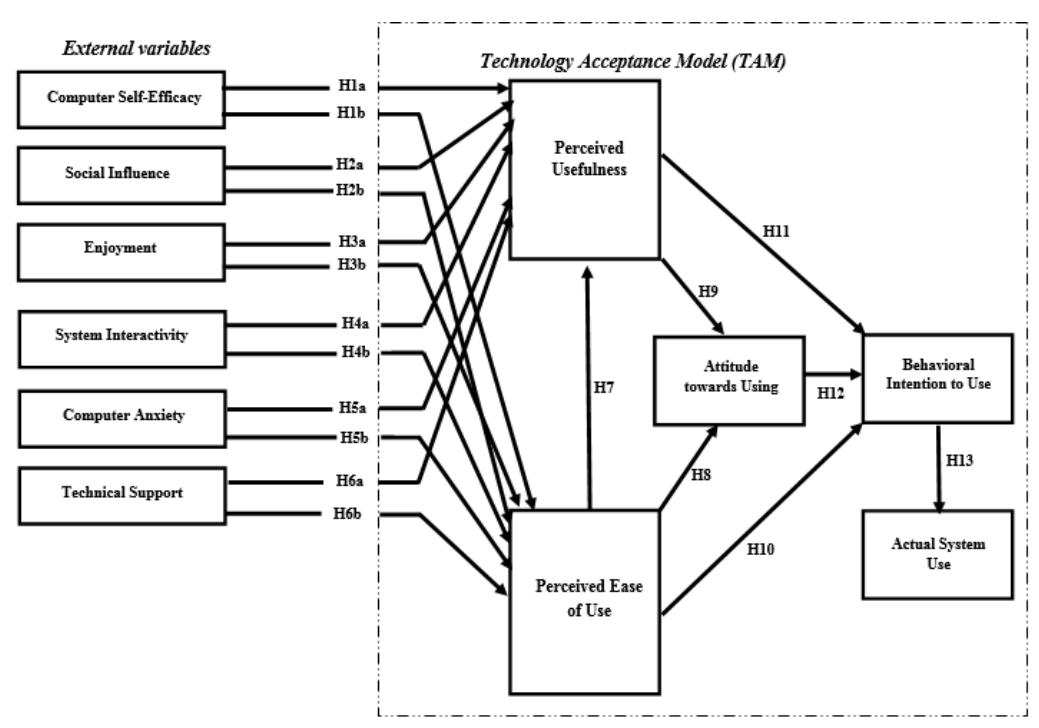

Fig. 1. The study model

\section{$4 \quad$ Research Methodology}

\subsection{Data collection}

Data collection process took place during the fall semester 2018/2019 from 15.10.2018 to 20.12.2018, with hard-copy surveys distributed among the students in the United Arab Emirates. There was random distribution of all of the 400 questionnaires, out of which 365 questionnaires were returned by the respondents, signifying an overall response rate of $91 \%$. Out of these, 35 of the questionnaires were rejected because some values were missing. Even though it is believed by [77] that 365 valid responses signifies an appropriate sample size, the proposed sampling size for a population of 1500 is 306 respondents. Hence, a sample size of 365 is greater than the proposed requirements, and is acceptable [78], which is why it is appropriate to use Structural Equation Modelling (SEM) to test the hypotheses. The hypotheses were formulated on the basis of the existing theories; however, they were also adapted to the context of e-learning. To evaluate the measurement model, SEM (SmartPLS Version 3.2.7) was used, and was ultimately treated with the final path model.

\subsection{Study instrument}

To A survey instrument presented in this research was used for hypothesis testing. The survey included 32 items for measuring the four constructs given in the questionnaire. The sources of these constructs are presented in Table 1. The questions given in 
the previous studies were altered and modified to improve the applicability of the research.

Table 1. Constructs and their sources.

\begin{tabular}{|l|c|l|}
\hline \multicolumn{1}{|c|}{ Constructs } & Number of items & \multicolumn{1}{c|}{ Source } \\
\hline Actual System Use & 2 & {$[75],[79]$} \\
\hline Attitude Towards Using & 3 & {$[22],[31],[65]$} \\
\hline Behavioral Intention to Use & 3 & {$[22],[65]$} \\
\hline Computer Anxiety & 3 & {$[20],[42],[51]$} \\
\hline Computer Self-Efficacy & 3 & {$[18],[33],[65]$} \\
\hline Enjoyment & 3 & {$[20],[33],[46]$} \\
\hline Perceived Ease of use & 3 & {$[18],[22],[46],[80]$} \\
\hline Perceived Usefulness & 3 & {$[20],[22],[46],[80],[81]$} \\
\hline Social Influence & 3 & {$[28],[82]$} \\
\hline System Interactivity & 3 & {$[41],[71],[83]$} \\
\hline Technical Support & 3 & {$[84],[85]$} \\
\hline
\end{tabular}

\subsection{Pilot study}

To assess the reliability of the questionnaire items, a pilot study was carried out, which included 40 students randomly selected from the given population to represent it appropriately. The basis of selecting the pilot study sample size was $10 \%$ of the overall sample size of the respondents of the study (400 students), which was consistent with the research standards. To evaluate the outcome of the pilot study, Cronbach's alpha test for internal reliability was used, which presented acceptable results for the measurement items. When refers to the usual pattern of social science research studies, it is believed that a reliability coefficient of 0.70 is acceptable [86]. The Cronbach alpha values for the 7 measurement scales given below are presented in Table 2.

Table 2. Cronbach's Alpha values for the pilot study (Cronbach's Alpha $\geq 0.70$ ).

\begin{tabular}{|l|c|}
\hline \multicolumn{1}{|c|}{ Construct } & Cronbach's Alpha \\
\hline Actual System Use & 0.799 \\
\hline Attitude Towards Using & 0.737 \\
\hline Behavioral Intention to Use & 0.920 \\
\hline Computer Anxiety & 0.793 \\
\hline Computer Self-Efficacy & 0.843 \\
\hline Enjoyment & 0.726 \\
\hline Perceived Ease of use & 0.887 \\
\hline Perceived Usefulness & 0.779 \\
\hline Social Influence & 0.769 \\
\hline System Interactivity & 0.828 \\
\hline Technical Support & 0.893 \\
\hline
\end{tabular}




\subsection{Survey structure}

The researcher circulated a single questionnaire survey: the hard-copy surveys were disseminated among students in the universities of the United Arab Emirates (UAE) $(\mathrm{N}=400)$. The study focuses on two distinct universities. These include the two most popular universities in the UAE, The British University in Dubai (BUiD) and University of Fujairah (UOF).

A questionnaire survey was developed and distributed among the students. There are three sections in the survey:

- The first section concentrates on the personal data of the participants.

- The second section stresses on the five items that represent the general question pertaining to mobile e-learning systems.

- The third section comprises of fifteen items that signify Expectation -Confirmation, Perceived Ease of Use, Perceived Usefulness, Satisfaction, and Social Influence.

To measure the 20 items, a five-point Likert Scale was used, ranging from strongly agreed (5), agree (4), neutral (3), disagree (2), and strongly disagree (1).

\subsection{Participants}

There was $56 \%$ female students and $44 \%$ male students. The student's ages were between 18 and 29 years for $63 \%$ of the respondents, whereas the ages of $37 \%$ of the respondents were more than 29 years old. Regarding the educational background, $43 \%$ of the students' major was in Business Administration, while $16 \%, 19 \%, 12 \%$, and $10 \%$ were from Engineering, Mass Communication and Public Relations, Social Sciences \& Humanities, and Information Technology background respectively. Most of the respondents were educated, having acquired university degrees. $58 \%$ of the students had a bachelor degree, $24 \%$ had a master's degree, and $18 \%$ had a doctoral degree, whereas the rest of the students had acquired diplomas. It was stated by [87] that the "purposive sampling approach" was employed when willingness is shown by the respondents for volunteering and when they are readily available. To declare, the study sample comprised of students from various colleges, studying in different programs at various levels, and belonging to different age groups.

\section{$5 \quad$ Findings and Discussion}

\subsection{Measurement model analysis}

The utilization of Smart PLS for the Partial Least Squares-Structural Equation Modeling (PLS-SEM) has been increasingly becoming widespread and [88] has created this software. The structural and measurement models were assessed via the PLSSEM in this research. The relationship the latent constructs have with each other is known as the structural model whereas the relationship that the indicators have with each other is called the measurement model (i.e., outer model) [89]. The greatest 
probability method and SEM-PLS were utilized to measure the proposed model [90]. For the calculation of convergent validity and reliability, Factor Loadings, Average Variance Extracted and Composite Reliability are part of the different measurements that took place. Factor loadings can be used for demonstrating the weight and correlation value of all questionnaire variables as perceived indicators, while the dimensionality of factors can be represented using bigger load value. Introducing the Composite Reliability (CR) measure resulted in the measurement of reliability. A precise value is provided by CR through the application of factor loadings in the constructed formula. Therefore, CR was made for the same reason. The average quantity of variance belonging to the provided variable that elaborates the latent construct is known as Average Variance Extracted (AVE). The utilization of AVE for analyzing the convergence of every factor is possible if the discriminate validity exceeds that one factor. As per Table 3, the criterion for the reliability and convergent validity has been fulfilled by the results of our experiment for the convergent validity and questionnaire reliability. Alongside the analysis results for all factors through the variable determined by the questionnaire, Table 3 outlines the validity and reliability of the questionnaire.

\subsection{Assessment of the measurement model (Outer model)}

In accordance with [91], factor loadings was used, variance extracted and reliability, containing Cronbach's Alpha and composite reliability, as indicators for estimating the relative amount of convergent validity. Various measurements of a construct have internal consistency as the reliability coefficient and composite reliability (CR) for all of constructs are more than 0.7 [91]. Table 3 shows that composite reliabilities of constructs are between 0.702 to 0.874 , while Cronbach's alpha values are more than the acceptable value of 0.7 [92], [93]. Additionally, every average variance extracted (AVE) values that are between 0.520 and 0.755 have explained almost half of variance extracted amongst a group of items significant to the latent construct, which is another requirement [94]. Consequently, the achievement of convergent validity is thought to be the outcome of the scales to evaluate the constructs.

All AVE values exceeding the squared correlation between the constructs in the measurement model results in satisfying the criteria of discriminant validity, in accordance with Table 4 [91], [95]. According to the recommendation, at least half of the measurement variance has to be determined by the construct if the AVE score exceeds 0.5. The discriminate value is determined using Partial Least Squares (SmartPLS). The loadings and cross-loadings are present in Table 6. The measurement items use their own latent constructs, rather than other constructs, for loading broadly, in accordance with a thorough evaluation of the loadings and cross-loadings. The correlations between the constructs are represented by the off-load diagonal elements, while the square root of the AVE values can be seen in the bold diagonal table. According to the table, the square root of the AVE values exceeds the suggested value of 0.5 , as their ranges are 0.759 and 0.935 . In comparison to other constructs in the model, the own measures result in a greater variance of all constructs as the AVE exceeds all correlations with the construct for every construct. Because of this, there is enhancement in the discriminate validity. According to [92], all items have to have 
a loading that exceeds that of its equivalent variable for satisfying the second condition of discriminate validity. Therefore, the second condition has been satisfied as well, as it can be seen from Table 4. The HTMT scores must not exceed 0.85 in order to satisfy the third condition of discriminant validity. There has been establishment of the discriminant validity, as the fulfillment of the third requirement can be noted from Table 5.

Table 3. Convergent validity results which assures acceptable values (Factor loading, Cronbach's Alpha, composite reliability $\geq 0.70 \&$ AVE > 0.5)

\begin{tabular}{|c|c|c|c|c|c|}
\hline Constructs & Items & Factor Loading & Cronbach's Alpha & $\mathbf{C R}$ & AVE \\
\hline \multirow{2}{*}{ Actual System Use } & ASU1 & 0.876 & \multirow{2}{*}{0.799} & \multirow{2}{*}{0.702} & \multirow{2}{*}{0.755} \\
\hline & ASU2 & 0.899 & & & \\
\hline \multirow{3}{*}{ Attitude towards Using } & ATU1 & 0.827 & \multirow{3}{*}{0.891} & \multirow{3}{*}{0.773} & \multirow{3}{*}{0.541} \\
\hline & ATU2 & 0.790 & & & \\
\hline & ATU3 & 0.809 & & & \\
\hline \multirow{3}{*}{ Behavioral Intention to Use } & BIU1 & 0.955 & \multirow{3}{*}{0.870} & \multirow{3}{*}{0.808} & \multirow{3}{*}{0.661} \\
\hline & BIU2 & 0.845 & & & \\
\hline & BIU3 & 0.819 & & & \\
\hline \multirow{3}{*}{ Computer Anxiety } & CA1 & 0.931 & \multirow{3}{*}{0.910} & \multirow{3}{*}{0.798} & \multirow{3}{*}{0.686} \\
\hline & CA2 & 0.822 & & & \\
\hline & CA3 & 0.725 & & & \\
\hline \multirow{3}{*}{ Computer Self-Efficacy } & CSE1 & 0.906 & \multirow{3}{*}{0.717} & \multirow{3}{*}{0.804} & \multirow{3}{*}{0.609} \\
\hline & CSE2 & 0.984 & & & \\
\hline & CSE3 & 0.771 & & & \\
\hline \multirow{3}{*}{ Enjoyment } & ENJ1 & 0.766 & \multirow[t]{3}{*}{0.797} & \multirow[t]{3}{*}{0.874} & \multirow[t]{3}{*}{0.753} \\
\hline & ENJ2 & 0.737 & & & \\
\hline & ENJ3 & 0.900 & & & \\
\hline \multirow{3}{*}{ Perceived Ease of use } & PEOU1 & 0.928 & \multirow{3}{*}{0.799} & \multirow{3}{*}{0.714} & \multirow{3}{*}{0.520} \\
\hline & PEOU2 & 0.849 & & & \\
\hline & PEOU3 & 0.770 & & & \\
\hline \multirow{3}{*}{ Perceived Usefulness } & PU1 & 0.852 & \multirow{3}{*}{0.888} & & \\
\hline & PU2 & 0.779 & & 0.843 & 0.528 \\
\hline & PU3 & 0.722 & & & \\
\hline & SI1 & 0.949 & & & \\
\hline Social Influence & SI2 & 0.869 & 0.750 & 0.707 & 0.551 \\
\hline & SI3 & 0.899 & & & \\
\hline & SIN1 & 0.703 & & & \\
\hline System Interactivity & SIN2 & 0.775 & 0.800 & 0.744 & 0.598 \\
\hline & SIN3 & 0.758 & & & \\
\hline & TS1 & 0.809 & & & \\
\hline Technical support & $\mathrm{TS} 2$ & 0.970 & 0.747 & 0.790 & 0.739 \\
\hline & TS3 & 0.787 & & & \\
\hline
\end{tabular}


Table 4. Fornell-Larcker Scale

\begin{tabular}{|l|c|c|c|c|c|c|c|c|c|c|c|}
\hline & ASU & ATU & BIU & CA & CSE & ENJ & PEOU & PU & SI & SIN & TA \\
\hline ASU & $\mathbf{0 . 8 8 6}$ & & & & & & & & & & \\
\hline ATU & 0.414 & $\mathbf{0 . 8 6 7}$ & & & & & & & & & \\
\hline BIU & 0.207 & 0.464 & $\mathbf{0 . 8 5 1}$ & & & & & & & & \\
\hline CA & 0.336 & 0.286 & 0.324 & $\mathbf{0 . 8 9 6}$ & & & & & & & \\
\hline CSE & 0.551 & 0.544 & 0.291 & 0.342 & $\mathbf{0 . 7 9 1}$ & & & & & & \\
\hline ENJ & 0.588 & 0.586 & 0.417 & 0.462 & 0.303 & $\mathbf{0 . 7 5 9}$ & & & & & \\
\hline PEOU & 0.288 & 0.585 & 0.617 & 0.502 & 0.403 & 0.451 & $\mathbf{0 . 7 8 6}$ & & & & \\
\hline PU & 0.544 & 0.282 & 0.507 & 0.363 & 0.438 & 0.129 & 0.356 & $\mathbf{0 . 9 1 7}$ & & & \\
\hline SI & 0.228 & 0.333 & 0.347 & 0.442 & 0.444 & 0.536 & 0.500 & 0.293 & $\mathbf{0 . 8 8 5}$ & & \\
\hline SIN & 0.232 & 0.345 & 0.378 & 0.399 & 0.342 & 0.334 & 0.542 & 0.333 & 0.505 & $\mathbf{0 . 9 3 5}$ & \\
\hline TA & 0.339 & 0.208 & 0.454 & 0.373 & 0.387 & 0.208 & 0.172 & 0.445 & 0.601 & 0.399 & $\mathbf{0 . 8 7 6}$ \\
\hline
\end{tabular}

Table 5. Heterotrait-Monotrait Ratio (HTMT)

\begin{tabular}{|l|c|c|c|c|c|c|c|c|c|c|c|}
\hline & ASU & ATU & BIU & CA & CSE & ENJ & PEOU & PU & SI & SIN & TA \\
\hline ASU & & & & & & & & & & & \\
\hline ATU & 0.633 & & & & & & & & & & \\
\hline BIU & 0.705 & 0.727 & & & & & & & & & \\
\hline CA & 0.758 & 0.223 & 0.242 & & & & & & & & \\
\hline CSE & 0.670 & 0.702 & 0.370 & 0.676 & & & & & & & \\
\hline ENJ & 0.757 & 0.777 & 0.760 & 0.701 & 0.535 & & & & & & \\
\hline PEOU & 0.214 & 0.376 & 0.223 & 0.572 & 0.767 & 0.299 & & & & & \\
\hline PU & 0.314 & 0.271 & 0.263 & 0.494 & 0.536 & 0.769 & 0.663 & & & & \\
\hline SI & 0.488 & 0.779 & 0.463 & 0.578 & 0.437 & 0.234 & 0.755 & 0.797 & & & \\
\hline SIN & 0.466 & 0.690 & 0.421 & 0.776 & 0.543 & 0.300 & 0.840 & 0.796 & 0.702 & & \\
\hline TA & 0.345 & 0.678 & 0.811 & 0.355 & 0.765 & 0.786 & 0.766 & 0.494 & 0.237 & 0.478 & \\
\hline
\end{tabular}

Table 6. Cross-loading results

\begin{tabular}{|l|c|c|c|c|c|c|c|c|c|c|c|}
\hline & ASU & ATU & BIU & CA & CSE & ENJ & PEOU & PU & SI & SIN & TA \\
\hline ASU1 & $\mathbf{0 . 8 7 6}$ & 0.357 & 0.444 & 0.567 & 0.317 & 0.670 & 0.363 & 0.325 & 0.567 & 0.464 & 0.252 \\
\hline ASU2 & $\mathbf{0 . 8 9 9}$ & 0.333 & 0.441 & 0.420 & 0.360 & 0.660 & 0.310 & 0.395 & 0.420 & 0.222 & 0.557 \\
\hline ATU1 & 0.270 & $\mathbf{0 . 8 2 7}$ & 0.300 & 0.376 & 0.645 & 0.510 & 0.412 & 0.319 & 0.376 & 0.375 & 0.454 \\
\hline ATU2 & 0.260 & $\mathbf{0 . 7 9 0}$ & 0.575 & 0.394 & 0.593 & 0.183 & 0.365 & 0.363 & 0.394 & 0.357 & 0.555 \\
\hline ATU3 & 0.310 & $\mathbf{0 . 8 0 9}$ & 0.409 & 0.402 & 0.110 & 0.293 & 0.419 & 0.487 & 0.402 & 0.343 & 0.591 \\
\hline BIU1 & 0.383 & 0.305 & $\mathbf{0 . 9 5 5}$ & 0.369 & 0.564 & 0.269 & 0.507 & 0.408 & 0.369 & 0.567 & 0.244 \\
\hline BIU2 & 0.293 & 0.212 & $\mathbf{0 . 8 4 5}$ & 0.493 & 0.552 & 0.222 & 0.442 & 0.342 & 0.493 & 0.264 & 0.225 \\
\hline BIU3 & 0.369 & 0.422 & $\mathbf{0 . 8 1 9}$ & 0.282 & 0.449 & 0.559 & 0.406 & 0.345 & 0.282 & 0.288 & 0.230 \\
\hline CA1 & 0.223 & 0.366 & 0.359 & $\mathbf{0 . 9 3 1}$ & 0.392 & 0.286 & 0.364 & 0.443 & 0.337 & 0.234 & 0.447 \\
\hline CA2 & 0.259 & 0.313 & 0.493 & $\mathbf{0 . 8 2 2}$ & 0.331 & 0.377 & 0.404 & 0.413 & 0.497 & 0.292 & 0.491 \\
\hline CA3 & 0.226 & 0.231 & 0.464 & $\mathbf{0 . 7 2 5}$ & 0.360 & 0.399 & 0.457 & 0.415 & 0.452 & 0.555 & 0.282 \\
\hline CSE1 & 0.472 & 0.294 & 0.444 & 0.317 & $\mathbf{0 . 9 0 6}$ & 0.300 & 0.469 & 0.452 & 0.485 & 0.481 & 0.543 \\
\hline CSE2 & 0.466 & 0.290 & 0.594 & 0.360 & $\mathbf{0 . 9 8 4}$ & 0.463 & 0.580 & 0.278 & 0.450 & 0.400 & 0.387 \\
\hline CSE3 & 0.234 & 0.238 & 0.399 & 0.645 & $\mathbf{0 . 7 7 1}$ & 0.182 & 0.446 & 0.372 & 0.452 & 0.487 & 0.235 \\
\hline ENJ1 & 0.363 & 0.339 & 0.345 & 0.593 & 0.567 & $\mathbf{0 . 7 6 6}$ & 0.380 & 0.400 & 0.226 & 0.233 & 0.392 \\
\hline ENJ2 & 0.382 & 0.382 & 0.381 & 0.510 & 0.420 & $\mathbf{0 . 7 3 7}$ & 0.439 & 0.503 & 0.213 & 0.233 & 0.433 \\
\hline ENJ3 & 0.231 & 0.278 & 0.376 & 0.564 & 0.376 & $\mathbf{0 . 9 0 0}$ & 0.480 & 0.458 & 0.290 & 0.334 & 0.122 \\
\hline
\end{tabular}




\begin{tabular}{|l|l|l|l|l|l|l|l|l|l|l|l|}
\hline PEOU1 & 0.117 & 0.380 & 0.209 & 0.331 & 0.531 & 0.394 & $\mathbf{0 . 9 2 8}$ & 0.528 & 0.496 & 0.075 & 0.316 \\
\hline PEOU2 & 0.300 & 0.305 & 0.319 & 0.360 & 0.600 & 0.402 & $\mathbf{0 . 8 4 9}$ & 0.531 & 0.376 & 0.345 & 0.532 \\
\hline PEOU3 & 0.345 & 0.481 & 0.460 & 0.341 & 0.690 & 0.369 & $\mathbf{0 . 7 7 0}$ & 0.508 & 0.380 & 0.540 & 0.378 \\
\hline PU1 & 0.393 & 0.450 & 0.570 & 0.437 & 0.738 & 0.493 & 0.363 & $\mathbf{0 . 8 5 2}$ & 0.399 & 0.300 & 0.276 \\
\hline PU2 & 0.410 & 0.499 & 0.562 & 0.369 & 0.739 & 0.282 & 0.310 & $\mathbf{0 . 7 7 9}$ & 0.440 & 0.240 & 0.568 \\
\hline PU3 & 0.464 & 0.586 & 0.508 & 0.420 & 0.582 & 0.337 & 0.412 & $\mathbf{0 . 7 2 2}$ & 0.413 & 0.343 & 0.593 \\
\hline SI1 & 0.542 & 0.258 & 0.415 & 0.420 & 0.378 & 0.497 & 0.365 & 0.325 & $\mathbf{0 . 9 4 9}$ & 0.279 & 0.472 \\
\hline SI2 & 0.444 & 0.558 & 0.396 & 0.451 & 0.304 & 0.452 & 0.419 & 0.395 & $\mathbf{0 . 8 6 9}$ & 0.279 & 0.448 \\
\hline SI3 & 0.292 & 0.451 & 0.430 & 0.451 & 0.472 & 0.485 & 0.507 & 0.319 & $\mathbf{0 . 8 9 9}$ & 0.204 & 0.146 \\
\hline SIN1 & 0.331 & 0.396 & 0.403 & 0.388 & 0.479 & 0.450 & 0.442 & 0.363 & 0.588 & $\mathbf{0 . 7 0 3}$ & 0.268 \\
\hline SIN2 & 0.330 & 0.465 & 0.497 & 0.388 & 0.389 & 0.452 & 0.406 & 0.487 & 0.460 & $\mathbf{0 . 7 7 5}$ & 0.293 \\
\hline SIN3 & 0.331 & 0.337 & 0.587 & 0.482 & 0.389 & 0.567 & 0.364 & 0.408 & 0.276 & $\mathbf{0 . 7 5 8}$ & 0.522 \\
\hline TS1 & 0.445 & 0.436 & 0.328 & 0.482 & 0.481 & 0.420 & 0.404 & 0.342 & 0.294 & 0.267 & $\mathbf{0 . 8 0 9}$ \\
\hline TS2 & 0.339 & 0.482 & 0.354 & 0.541 & 0.455 & 0.376 & 0.457 & 0.345 & 0.422 & 0.520 & $\mathbf{0 . 9 7 0}$ \\
\hline TS3 & 0.423 & 0.464 & 0.308 & 0.496 & 0.481 & 0.394 & 0.469 & 0.443 & 0.339 & 0.376 & $\mathbf{0 . 7 8 7}$ \\
\hline
\end{tabular}

\subsection{Assessment of structural model (Inner model)}

It is usually the case that the coefficient of determination ( $R 2$ value) measure is used to examine the structural model. The model's predictive accuracy is determined with this coefficient, whose processing is done as the squared correlation between the predicted and actual values of a certain endogenous construct. The coefficient represents the collective impact of the exogenous latent variables on endogenous latent variable. How much variance is there in the endogenous constructs defended by all exogenous constructs alongside it can be determined through this coefficient, as it is the squared correlation between the variables' predicted and actual scores. The values are weak when they are between 0.19-0.33, direct when they are between 0.33-0.67, high when they exceed 0.67 and inadmissible when the estimation is lower than 0.19 [89]. According to Table 7 and Figure 2, the model has a moderate predictive power, which supports virtually almost $56 \%, 49 \%, 33 \%, 58 \%$ and $62 \%$ of the variance in the actual system use, attitude towards using, behavioral intention to used, perceived usefulness, and perceived ease of use respectively.

Table 7. R2 of the endogenous latent variables

\begin{tabular}{|l|c|l|}
\hline \multicolumn{1}{|c|}{ Constructs } & \multicolumn{1}{c|}{$\mathbf{R}^{\mathbf{2}}$} & \multicolumn{1}{c|}{ Results } \\
\hline Actual system use & 0.557 & Moderate \\
\hline Attitude towards using & 0.491 & Moderate \\
\hline Behavioral intention to used & 0.327 & Moderate \\
\hline Perceived Usefulness & 0.584 & Moderate \\
\hline Perceived Ease of Use & 0.623 & Moderate \\
\hline
\end{tabular}

\subsection{Structural model analysis}

The proposed hypotheses were tested as the associations amongst the theoretical constructs for the structural model were assessed with the utilization of a structural equation model via SEM-PLS alongside the maximum likelihood estimation [96]- 
[102]. In Table 8 and Figure 2, the summary of the results can be found. All hypotheses were found to be significant. Based on the data analysis hypotheses H1a, H1b, H2a, H2b, H3a, H3b, H4a, H4b, H5a, H5b, H6a, H6b, H7, H8, H9, H10, H11, H12 and $\mathrm{H} 13$ were supported by the empirical data. The results showed that Perceived Usefulness (PU) significantly influenced Computer Self-Efficacy (CSE) $(\beta=0.145$, $\mathrm{P}<0.05)$, Social Influence $(\mathrm{SI})(\beta=0.832, \mathrm{P}<0.001)$, Enjoyment $(\mathrm{ENJ})(\beta=0.735$, $\mathrm{P}<0.001)$, System Interactivity (SIN) $(\beta=0.108, \mathrm{P}<0.05)$, Computer Anxiety (CA) $(\beta=$ $0.348, \mathrm{P}<0.001)$, Technical support (TS) $(\beta=0.283, \mathrm{P}<0.001)$, and Perceived Ease of Use (PEOU) $(\beta=0.236, \mathrm{P}<0.05)$ supporting hypothesis H1a, H2a, H3a, H4a, H5a, H6a, and H7 respectively. Perceived Ease of Use (PEOU) was determined to be significant in affecting Computer Self-Efficacy (CSE) $(\beta=0.579, \mathrm{P}<0.001)$, Social Influence (SI) $(\beta=0.436, P<0.001)$, Enjoyment (ENJ) $(\beta=0.293, P<0.05)$, System Interactivity (SIN) $(\beta=0.537, \mathrm{P}<0.001)$, Computer Anxiety $(\mathrm{CA})(\beta=0.681, \mathrm{P}<0.001)$, and Technical support (TS) $(\beta=0.124, \mathrm{P}<0.05)$ supporting hypothesis H1b, H2b, H3b, $\mathrm{H} 4 \mathrm{~b}, \mathrm{H} 5 \mathrm{~b}$, and $\mathrm{H} 6 \mathrm{~b}$ respectively. Furthermore, Attitude towards using (ATU) was significantly influenced by Perceived Ease of Use (PEOU) $(\beta=0.577, \mathrm{P}<\mathrm{P}<0.05)$ and Perceived Usefulness (PU) $(\beta=0.279, \mathrm{P}<\mathrm{P}<0.05)$ which support hypotheses H8 and H9. Behavioral intention to used (BIU) significantly influenced Perceived Ease of Use (PEOU) $(\beta=0.420, \mathrm{P}<0.001)$, Perceived Usefulness (PU) $(\beta=0.567, \mathrm{P}<0.05)$, and Attitude towards using (ATU) $(\beta=0.604, \mathrm{P}<0.05)$ supporting hypothesis H10, H11 and $\mathrm{H} 12$ respectively. The results also revealed that Behavioral intention to used (BIU) significantly influenced Actual system use (ASU) $(\beta=0.736 \mathrm{P}<0.001)$ supporting hypothesis H13. A summary of the hypotheses testing results is shown in Table 8.

Table 8. Results of structural Model - Research Hypotheses Significant at $\mathrm{p}^{* *}=<0.01, \mathrm{p}^{*}$ $<0.05$ Significant at $\left.\mathrm{p}^{* *}=<0.01, \mathrm{p}^{*}<0.05\right)$

\begin{tabular}{|c|c|c|c|c|c|c|}
\hline $\mathbf{H}$ & Relationship & Path & $t$-value & $p$-value & Direction & Decision \\
\hline H1a & $\begin{array}{l}\text { Computer Self-Efficacy -> Per- } \\
\text { ceived Usefulness }\end{array}$ & 0.145 & 1.770 & 0.043 & Positive & Supported* \\
\hline $\mathrm{H} 1 \mathrm{~b}$ & $\begin{array}{l}\text { Computer Self-Efficacy -> Per- } \\
\text { ceived Ease of Use }\end{array}$ & 0.579 & 8.337 & 0.001 & Positive & Supported $* *$ \\
\hline $\mathrm{H} 2 \mathrm{a}$ & $\begin{array}{l}\text { Social Influence } \\
->\text { Perceived Usefulness }\end{array}$ & 0.832 & 11.880 & 0.000 & Positive & Supported** \\
\hline $\mathrm{H} 2 \mathrm{~b}$ & $\begin{array}{l}\text { Social Influence -> Perceived Ease } \\
\text { of Use }\end{array}$ & 0.436 & 2.292 & 0.004 & Positive & Supported $* *$ \\
\hline $\mathrm{H} 3 \mathrm{a}$ & Enjoyment -> Perceived Usefulness & 0.735 & 17.558 & 0.000 & Positive & Supported $* *$ \\
\hline $\mathrm{H} 3 \mathrm{~b}$ & $\begin{array}{l}\text { Enjoyment -> Perceived Ease of } \\
\text { Use }\end{array}$ & 0.293 & 2.330 & 0.011 & Positive & Supported* \\
\hline $\mathrm{H} 4 \mathrm{a}$ & $\begin{array}{l}\text { System Interactivity -> Perceived } \\
\text { Usefulness }\end{array}$ & 0.108 & 3.113 & 0.031 & Positive & Supported* \\
\hline $\mathrm{H} 4 \mathrm{~b}$ & $\begin{array}{l}\text { System Interactivity -> Perceived } \\
\text { Ease of Use }\end{array}$ & 0.537 & 37.459 & 0.000 & Positive & Supported** \\
\hline H5a & $\begin{array}{l}\text { Computer Anxiety -> Perceived } \\
\text { Usefulness }\end{array}$ & 0.348 & 20.696 & 0.000 & Positive & Supported $* *$ \\
\hline $\mathrm{H} 5 \mathrm{~b}$ & $\begin{array}{l}\text { Computer Anxiety -> Perceived } \\
\text { Ease of Use }\end{array}$ & 0.681 & 16.494 & 0.000 & Positive & Supported** \\
\hline H6a & $\begin{array}{l}\text { Technical support -> Perceived } \\
\text { Usefulness }\end{array}$ & 0.283 & 24.817 & 0.000 & Positive & Supported** \\
\hline
\end{tabular}


Paper-An Empirical Investigation into Examination of Factors Influencing University Students'..

\begin{tabular}{|l|l|c|c|c|l|l|}
\hline H6b & $\begin{array}{l}\text { Technical support -> Perceived } \\
\text { Ease of Use }\end{array}$ & 0.124 & 3.115 & 0.033 & Positive & Supported* \\
\hline H7 & $\begin{array}{l}\text { Perceived Ease of Use -> Perceived } \\
\text { Usefulness }\end{array}$ & 0.236 & 6.426 & 0.043 & Positive & Supported* \\
\hline H8 & $\begin{array}{l}\text { Perceived Ease of Use -> Attitude } \\
\text { towards using }\end{array}$ & 0.577 & 1.178 & 0.039 & Positive & Supported* \\
\hline H9 & $\begin{array}{l}\text { Perceived Usefulness -> Attitude } \\
\text { towards using }\end{array}$ & 0.279 & 1.119 & 0.046 & Positive & Supported* \\
\hline H10 & $\begin{array}{l}\text { Perceived Ease of Use -> Behavior- } \\
\text { al intention to used }\end{array}$ & 0.420 & 39.821 & 0.000 & Positive & Supported** \\
\hline H11 & $\begin{array}{l}\text { Perceived Usefulness -> Behavioral } \\
\text { intention to used }\end{array}$ & 0.567 & 3.022 & 0.034 & Positive & Supported* \\
\hline H12 & $\begin{array}{l}\text { Attitude towards using -> Behav- } \\
\text { ioral intention to used }\end{array}$ & 0.604 & 1.329 & 0.015 & Positive & Supported* \\
\hline H13 & $\begin{array}{l}\text { Behavioral intention to used -> } \\
\text { Actual system use }\end{array}$ & 0.736 & 29.901 & 0.000 & Positive & Supported $* *$ \\
\hline
\end{tabular}

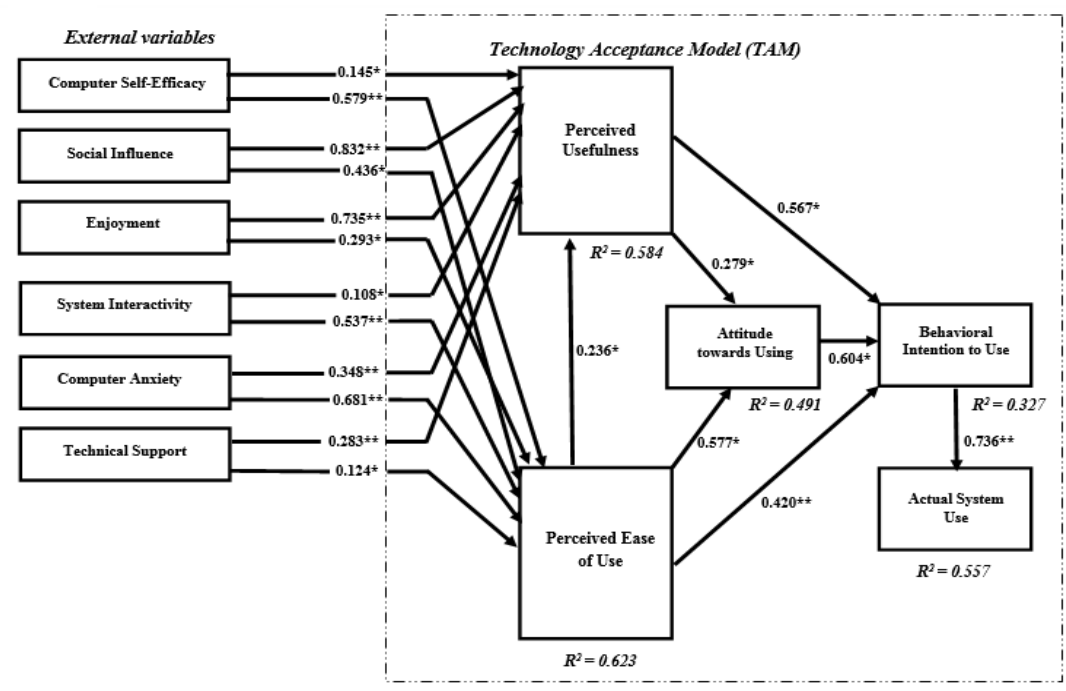

Fig. 2. Path coefficient results (significant at $\mathrm{p}^{* *}<=0.01, \mathrm{p}^{*}<0.05$ )

\section{Discussion and Implication}

The purpose of carrying out this research was to determine the critical factors in Elearning adoption and acceptance in the UAE. The statistical analysis of the critical factors concluded that "Computer Self-Efficacy", "Social Influence", "Enjoyment", "System Interactivity", "Computer Anxiety", and "Technical support" have positive and significant influences on perceived usefulness, and perceived ease of use. In addition, perceived usefulness, and perceived ease of use were found to be significant in influencing on behavioral intention to use E-learning system. The study plays a vital role in recognizing and investigating the influential factors of learners' attitudes in terms of adoption and acceptance of e-learning systems. Further insights are offered 
by the study outcomes regarding the external factors, as well as critical suggestions for policy makers, practitioners, developers, and designers for effectively adopting the e-learning systems. The study used a stringent research procedure; however, future studies may recognize and explain certain possible limitations that continue to exist. There was low response rate of participants from the University of Fujairah, UAE. The population of UAE that use the E-learning systems was used to deduce the results and implications. Hence, because of cross-cultural distinctions among the provinces and so the generalizability of the results should be considered carefully. The intention of learners to adopt an E-learning system was also the basis of this study, even though a critical role was also played by the faculty in determining intention to adopt. The part played by the faculty in the adoption of e-learning system can be assessed in forthcoming studies. To bridge the gap between the design and execution of elearning and actual usage, it is important to concentrate on the factors identified for TAM. Support should be offered to using virtual worlds in higher education; however, this kind of use should be properly integrated in the prevailing educational procedures. It is vital to have technology-pertinent training and support, and the infrastructure required to suitably execute an e-learning system so that the virtual worlds can be effectively introduced in higher education. When further factors are added to the model, for example users' satisfaction to determine the adoption of e-learning, TAM in higher education can be understood more adequately.

\section{$7 \quad$ References}

[1] D. U. Vidanagama, "Acceptance of E-Learning among Undergraduates of Computing Degrees in Sri Lanka," Int. J. Mod. Educ. Comput. Sci., vol. 8, no. 4, p. 25, 2016.

[2] D. S. Priyangika and C. Chiran, "IT students' perceptions on e-learning: a preliminary survey at University of Colombo," 2012.

[3] F. D. Davis, "Perceived usefulness, perceived ease of use, and user acceptance of information technology," MIS Q., pp. 319-340, 1989. https://doi.org/10.2307/249008

[4] V. Venkatesh and H. Bala, "Technology acceptance model 3 and a research agenda on interventions," Decis. Sci., vol. 39, no. 2, pp. 273-315, 2008.

[5] L. N. Proffitt, "A study of the influence of learner readiness on academic success and student perceptions of online learning," A Diss. Present. Partial fulfilment Requir. degree Dr. Philos. Capella Univ., 2008.

[6] D. Shen, J. Laffey, Y. Lin, and X. Huang, "Social influence for perceived usefulness and ease-of-use of course delivery systems," J. Interact. Online Learn, vol. 5, no. 3, pp. 270282, 2006.

[7] T. Farahat, "Applying the technology acceptance model to online learning in the Egyptian universities," Procedia-Social Behav. Sci., vol. 64, pp. 95-104, 2012. https://doi.org/10.10 16/j.sbspro.2012.11.012

[8] M. Alshurideh, "The Factors Predicting Students' Satisfaction with Universities' Healthcare Clinics' Services: A Case-Study from the Jordanian Higher Education Sector," Dirasat Adm. Sci., vol. 41, no. 2, pp. 451-464, 2014. https://doi.org/10.12816/0007482

[9] M. Alshurideh, M. Nicholson, and S. Xiao, "The Effect of Previous Experience on Mobile Subscribers' Repeat Purchase Behaviour,” Eur. J. Soc. Sci., vol. 30, no. 3, pp. 366-376, 2012. 
[10] B. Šumak, M. Heričko, M. Pušnik, and G. Polančič, "Factors affecting acceptance and use of Moodle: An empirical study based on TAM," Informatica, vol. 35, no. 1, 2011.

[11] M. T. Alshurideh, "A Qualitative Analysis of Customer Repeat Purchase Behaviour in the UK Mobile Phone Market,” J. Manag. Res., vol. 6, no. 1, pp. 109-125, 2013. https://doi. org/10.5296/jmr.v6i1.4659

[12] R. M. Al-dweeri, Z. M. Obeidat, M. A. Al-dwiry, M. T. Alshurideh, and A. M. Alhorani, "The impact of e-service quality and e-loyalty on online shopping: moderating effect of esatisfaction and e-trust,” Int. J. Mark. Stud., vol. 9, no. 2, p. 92, 2017. https://doi.org/10.55 39/ijms.v9n2p92

[13] S. A. Salloum, C. Mhamdi, B. Al Kurdi, and K. Shaalan, "Factors affecting the Adoption and Meaningful Use of Social Media: A Structural Equation Modeling Approach,” Int. J. Inf. Technol. Lang. Stud., vol. 2, no. 3, pp. 96-109, 2018.

[14] E. Adewole-Odeshi, "Attitude of Students Towards E-learning in South-West Nigerian Universities: An Application of Technology Acceptance Model," Libr. Philos. Pract., p. 0_1, 2014.

[15] D. R. Compeau and C. A. Higgins, "Computer self-efficacy: Development of a measure and initial test," MIS Q., pp. 189-211, 1995. https://doi.org/10.2307/249688

[16] D. R. Compeau and C. A. Higgins, "Application of social cognitive theory to training for computer skills,” Inf. Syst. Res., vol. 6, no. 2, pp. 118-143, 1995.

[17] H. Haryanto and H. U. Kultsum, "E-Learning Program Adoption: Technology Acceptance Model Approach," in Proceeding of the International Conference on Teacher Training and Education, 2016, vol. 2, no. 1, pp. 616-622.

[18] S. Y. Park, "An analysis of the technology acceptance model in understanding university students' behavioral intention to use e-learning," J. Educ. Technol. Soc., vol. 12, no. 3, p. $150,2009$.

[19] M. Chow, D. K. Herold, T.-M. Choo, and K. Chan, "Extending the technology acceptance model to explore the intention to use Second Life for enhancing healthcare education," Comput. Educ., vol. 59, no. 4, pp. 1136-1144, 2012. https://doi.org/10.1016/j.compedu.20 12.05 .011

[20] C.-T. Chang, J. Hajiyev, and C.-R. Su, "Examining the students' behavioral intention to use e-learning in Azerbaijan? The General Extended Technology Acceptance Model for Elearning approach,” Comput. Educ., vol. 111, pp. 128-143, 2017. https://doi.org/10.1016/j. compedu.2017.04.010

[21] R. Hussein, U. Aditiawarman, and N. Mohamed, "E-learning acceptance in a developing country: a case of the Indonesian Open University," in German e-Science conference, 2007.

[22] N. Fathema, D. Shannon, and M. Ross, "Expanding The Technology Acceptance Model (TAM) to Examine Faculty Use of Learning Management Systems (LMSs) In Higher Education Institutions.," J. Online Learn. Teach., vol. 11, no. 2, 2015.

[23] A. A. Rabaa'i, "Extending the Technology Acceptance Model (TAM) to assess Students' Behavioural Intentions to adopt an e-Learning System: The Case of Moodle as a Learning Tool," J. Emerg. Trends Eng. Appl. Sci., vol. 7, no. 1, pp. 13-30, 1975.

[24] K. N. N. Tran, "The Adoption of Blended E-learning Technology in Vietnam using a Revision of the Technology Acceptance Model.," J. Inf. Technol. Educ., vol. 15, 2016.

[25] J.-W. Hsia, C.-C. Chang, and A.-H. Tseng, "Effects of individuals' locus of control and computer self-efficacy on their e-learning acceptance in high-tech companies," Behav. Inf. Technol., vol. 33, no. 1, pp. 51-64, 2014. https://doi.org/10.1080/0144929x.2012.702284

[26] N. F. A. Al-Mushasha, "Determinants of e-learning acceptance in higher education environment based on extended technology acceptance model," in e-Learning" Best Practices 
in Management, Design and Development of e-Courses: Standards of Excellence and Creativity", 2013 Fourth International Conference on, 2013, pp. 261-266. https://doi. org/10.1109/econf.2013.50

[27] F. Kanwal and M. Rehman, "Factors Affecting E-Learning Adoption in Developing Countries-Empirical Evidence from Pakistan's Higher Education Sector,” IEEE Access, 2017. https://doi.org/10.1109/access.2017.2714379

[28] J. H. Al-Ammary, A. K. Al-Sherooqi, and H. K. Al-Sherooqi, "The acceptance of social networking as a learning tools at University of Bahrain,” Int. J. Inf. Educ. Technol., vol. 4, no. 2, p. 208, 2014. https://doi.org/10.7763/ijiet.2014.v4.400

[29] C. Yi-Cheng, C. Chun-Yu, L. Yi-Chen, and Y. Ron-Chen, "Predicting college student'use of e-learning systems: an attempt to extend technology acceptance model," PACIS 2007 Proc., p. 121, 2007.

[30] M. Abbad, D. Morris, A. E. Al-Ayyoub, and J. Abbad, "Students' Decisions to Use an eLearning System: A Structural Equation Modelling Analysis.," iJET, vol. 4, no. 4, pp. 413, 2009. https://doi.org/10.3991/ijet.v4i4.928

[31] A. Alia, "An investigation of the application of the Technology Acceptance Model (TAM) to evaluate instructors' perspectives on E-Learning at Kuwait University.” Dublin City University, 2016.

[32] R. Boateng, A. S. Mbrokoh, L. Boateng, P. K. Senyo, and E. Ansong, "Determinants of elearning adoption among students of developing countries," Int. J. Inf. Learn. Technol., vol. 33, no. 4, pp. 248-262, 2016. https://doi.org/10.1108/ijilt-02-2016-0008

[33] Y.-C. Lin, Y.-C. Chen, and R. C. Yeh, "Understanding college students' continuing intentions to use multimedia e-learning systems," World Trans. Eng. Technol. Educ., vol. 8, no. 4, pp. 488-493, 2010.

[34] M. Mahmodi, "The Analysis of the Factors Affecting the Acceptance of E-learning in Higher Education,” Interdiscip. J. Virtual Learn. Med. Sci., vol. 8, no. 1, 2017. https://doi. org/10.5812/ijvlms. 11158

[35] A. Revythi and N. Tselios, "Extension of Technology Acceptance Model by using System Usability Scale to assess behavioral intention to use e-learning," arXiv Prepr. arXiv1704.06127, 2017. https://doi.org/10.1007/s10639-019-09869-4

[36] M. Fishbein and I. Ajzen, Belief, attitude, intention and behavior: An introduction to theory and research. 1975 .

[37] V. Venkatesh, M. G. Morris, G. B. Davis, and F. D. Davis, "User acceptance of information technology: Toward a unified view," MIS Q., pp. 425-478, 2003. https://doi. org/10.2307/30036540

[38] B. AL KURDI, "Healthy-Food Choice and Purchasing Behaviour Analysis: An Exploratory Study of Families in the UK." Durham University, 2016.

[39] M. ALSHURIDEH, "Customer Service Retention-A Behavioural Perspective of the UK Mobile Market.” Durham University, 2010.

[40] A. M. Elkaseh, K. W. Wong, and C. C. Fung, "The Acceptance of e-learning as a tool for teaching and learning in Libyan higher education,” IPASJ Int. J. Inf. Technol., vol. 3, no. 4, pp. 1-11, 2015.

[41] V. Moreno, F. Cavazotte, and I. Alves, "Explaining university students' effective use of elearning platforms,” Br. J. Educ. Technol., vol. 48, no. 4, pp. 995-1009, 2017. https://doi. org/10.1111/bjet.12469

[42] S. S. Al-Gahtani, "Empirical investigation of e-learning acceptance and assimilation: A structural equation model," Appl. Comput. Informatics, vol. 12, no. 1, pp. 27-50, 2016. https://doi.org/10.1016/j.aci.2014.09.001 
[43] S. Alharbi and S. Drew, "Using the technology acceptance model in understanding academics' behavioural intention to use learning management systems," Int. J. Adv. Comput. Sci. Appl., vol. 5, no. 1, pp. 143-155, 2014.

[44] V. Venkatesh, "Determinants of perceived ease of use: Integrating control, intrinsic motivation, and emotion into the technology acceptance model," Inf. Syst. Res., vol. 11, no. 4, pp. 342-365, 2000. https://doi.org/10.1287/isre.11.4.342.11872

[45] P. E. Ramírez-Correa, J. Arenas-Gaitán, and F. J. Rondán-Cataluña, "Gender and acceptance of E-learning: a multi-group analysis based on a structural equation model among college students in Chile and Spain," PLoS One, vol. 10, no. 10, p. e0140460, 2015. https://doi.org/10.1371/journal.pone.0140460

[46] M. R. Martínez-Torres, S. L. Toral Marín, F. B. Garcia, S. G. Vazquez, M. A. Oliva, and T. Torres, "A technological acceptance of e-learning tools used in practical and laboratory teaching, according to the European higher education area," Behav. Inf. Technol., vol. 27, no. 6, pp. 495-505, 2008. https://doi.org/10.1080/01449290600958965

[47] B. Cheng, M. Wang, J. Moormann, B. A. Olaniran, and N.-S. Chen, "The effects of organizational learning environment factors on e-learning acceptance," Comput. Educ., vol. 58, no. 3, pp. 885-899, 2012. https://doi.org/10.1016/j.compedu.2011.10.014

[48] C.-L. Wang, N. Y. M. Siu, and A. S. Y. Hui, "Consumer decision-making styles on domestic and imported brand clothing," Eur. J. Mark., vol. 38, no. 1/2, pp. 239-252, 2004. https://doi.org/10.1108/03090560410511212

[49] S.-C. Lin, S. F. Persada, and R. Nadlifatin, "A study of student behavior in accepting the Blackboard Learning System: A Technology Acceptance Model (TAM) approach," in Computer Supported Cooperative Work in Design (CSCWD), Proceedings of the 2014 IEEE 18th International Conference on, 2014, pp. 457-462. https://doi.org/10.1109/cscwd. 2014.6846888

[50] G. S. Howard and R. D. Smith, "Computer anxiety in management: Myth or reality?," Commun. ACM, vol. 29, no. 7, pp. 611-615, 1986. https://doi.org/10.1145/6138.6143

[51] J. Attis, An investigation of the variables that predict teacher e-learning acceptance. Liberty University, 2014.

[52] A. Jashapara and W.-C. Tai, "Knowledge mobilization through e-learning systems: Understanding the mediating roles of self-efficacy and anxiety on perceptions of ease of use," Inf. Syst. Manag., vol. 28, no. 1, pp. 71-83, 2011. https://doi.org/10.1080/10580530. $\underline{2011.536115}$

[53] M. Rezaei, H. M. Mohammadi, A. Asadi, and K. Kalantary, "Predicting e-learning application in agricultural higher education using technology acceptance model," Turkish Online J. Distance Educ., vol. 9, no. 1, 2008.

[54] A. R. Alenezi and A. Karim, "An empirical investigation into the role of enjoyment, computer anxiety, computer self-efficacy and internet experience in influencing the students' intention to use e-learning: A case study from Saudi Arabian governmental universities.," Turkish Online J. Educ. Technol., vol. 9, no. 4, pp. 22-34, 2010.

[55] R. Wilson and M. Illustrator-Stein, Help!: The art of computer technical support. Peachpit Press, 1995.

[56] R. Arteaga Sánchez, A. Duarte Hueros, and M. García Ordaz, "E-learning and the University of Huelva: a study of WebCT and the technological acceptance model," Campus-Wide Inf. Syst., vol. 30, no. 2, pp. 135-160, 2013. https://doi.org/10.1108/10650741311306318

[57] F. D. Davis, "Perceived Usefulness, Perceived Ease of Use, and User Acceptance of Information Technology," MIS Q., vol. 13, no. 3, pp. 319-340, 1989. https://doi.org/10. $\underline{2307 / 249008}$ 
[58] A. Al-Adwan, A. Al-Adwan, and J. Smedley, "Exploring students acceptance of e-learning using Technology Acceptance Model in Jordanian universities," Int. J. Educ. Dev. Using Inf. Commun. Technol., vol. 9, no. 2, p. 4, 2013.

[59] M. Masrom, "Technology acceptance model and e-learning," Technology, vol. 21, no. 24, p. 81, 2007.

[60] Y.-L. Theng et al., “An empirical study of students' perceptions on e-learning systems," in Proceedings of the 2nd International Convention on Rehabilitation Engineering \& Assistive Technology, 2008, pp. 245-249.

[61] S. A. S. Salloum and K. Shaalan, 'Investigating students' acceptance of E-learning system in Higher Educational Environments in the UAE: Applying the Extended Technology Acceptance Model (TAM)." The British University in Dubai, 2018.

[62] J.-W. Hsia and A.-H. Tseng, "An enhanced technology acceptance model for e-learning systems in high-tech companies in Taiwan: analyzed by structural equation modeling," in Cyberworlds, 2008 International Conference on, 2008, pp. 39-44. https://doi.org/10.1109/ cw. 2008.46

[63] V. Muniasamy, I. Magboul Eljailani, and M. Anandhavalli, "Prediction of Learner Perception and Acceptance of E-Learning System for Learning with TAM (Technology Acceptance Model) in King Khalid University, Kingdom of Saudi Arabia,” Int. J. Emerg. Technol. Adv. Eng., vol. 4, no. 9, pp. 94-99, 2014.

[64] J. Rissa, "An empirical study on the e-learning acceptance among the Finnish labor," 2014.

[65] B. Rym, B. Olfa, and B. M. Mélika, "Determinants of e-learning acceptance: An empirical study in the Tunisian context,” Am. J. Ind. Bus. Manag., vol. 3, no. 3, p. 307, 2013. https:// doi.org/10.4236/ajibm.2013.33036

[66] P. Mbengo, "E-learning adoption by lecturers in selected Zimbabwe State Universities: an application of technology acceptance model," J. Bus. Adm. Educ., vol. 6, no. 1, 2014.

[67] C.-H. Ku, Extending the technology acceptance model using perceived user resources in higher education web-based online learning courses. University of Central Florida, 2009.

[68] O. A. Jaber, "An Examination of Variables Influencing the Acceptance and Usage of ELearning Systems in Jordanian Higher Education Institutions.” Cardiff Metropolitan University, 2016.

[69] S. Baleghi-Zadeh, A. F. M. Ayub, R. Mahmud, and S. M. Daud, "Behaviour Intention to Use the Learning Management: Integrating Technology Acceptance Model with TaskTechnology Fit,” Middle-East J. Sci. Res., vol. 19, no. 1, pp. 76-84, 2014.

[70] S. A. M. Shah, N. Iqbal, S. Y. Janjua, and S. Amjad, "Employee behavior towards adoption of e-learning courses: validating technology acceptance model," Mediterr. J. Soc. Sci., vol. 4, no. 14, p. 765, 2013. https://doi.org/10.5901/mjss.2013.v4n14p765

[71] Y.-M. Cheng, "Effects of quality antecedents on e-learning acceptance," Internet Res., vol. 22, no. 3, pp. 361-390, 2012.

[72] I. Rodríguez-Ardura and A. Meseguer-Artola, "What leads people to keep on e-learning? An empirical analysis of users' experiences and their effects on continuance intention," Interact. Learn. Environ., vol. 24, no. 6, pp. 1030-1053, 2016. https://doi.org/10.1080/10494 $\underline{820.2014 .926275}$

[73] I. Akman and C. Turhan, "User acceptance of social learning systems in higher education: an application of the extended Technology Acceptance Model," Innov. Educ. Teach. Int., vol. 54, no. 3, pp. 229-237, 2017. https://doi.org/10.1080/14703297.2015.1093426

[74] E. T. Khor, "An analysis of ODL student perception and adoption behavior using the technology acceptance model,” Int. Rev. Res. Open Distrib. Learn., vol. 15, no. 6, 2014. 
[75] R. Cheung and D. Vogel, "Predicting user acceptance of collaborative technologies: An extension of the technology acceptance model for e-learning," Comput. Educ., vol. 63, pp. 160-175, 2013. https://doi.org/10.1016/j.compedu.2012.12.003

[76] L. M. Renda dos Santos and S. Okazaki, "Planned e-learning adoption and occupational socialisation in Brazilian higher education," Stud. High. Educ., vol. 41, no. 11, pp. 19741994, 2016. https://doi.org/10.1080/03075079.2015.1007940

[77] R. V Krejcie and D. W. Morgan, "Determining sample size for research activities," Educ. Psychol. Meas., vol. 30, no. 3, pp. 607-610, 1970.

[78] C. L. Chuan and J. Penyelidikan, "Sample size estimation using Krejcie and Morgan and Cohen statistical power analysis: A comparison," J. Penyelid. IPBL, vol. 7, pp. 78-86, 2006.

[79] H. Mohammadi, "Investigating users' perspectives on e-learning: An integration of TAM and IS success model," Comput. Human Behav., vol. 45, pp. 359-374, 2015. https://doi. org/10.1016/j.chb.2014.07.044

[80] C.-S. Ong and J.-Y. Lai, "Gender differences in perceptions and relationships among dominants of e-learning acceptance," Comput. Human Behav., vol. 22, no. 5, pp. 816-829, 2006. https://doi.org/10.1016/j.chb.2004.03.006

[81] J. C. Roca, C.-M. Chiu, and F. J. Martínez, "Understanding e-learning continuance intention: An extension of the Technology Acceptance Model," Int. J. Hum. Comput. Stud., vol. 64, no. 8, pp. 683-696, 2006.

[82] S. Patil, P. N. Razdan, and V. Chancellor, "Creating awareness acceptance and application of e-learning in higher education institutions: using technology acceptance model (TAM)," Int. J. Multidiscip. Consort., vol. 2, no. 4, 2015.

[83] Y. Cheng, “Antecedents and consequences of e-learning acceptance," Inf. Syst. J., vol. 21, no. 3, pp. 269-299, 2011.

[84] I. Govender and I. Rootman-le Grange, "Evaluating the Early Adoption of Moodle at a Higher Education Institution," in European Conference on e-Learning, 2015, p. 230.

[85] A. R. Alenezi, A. M. Abdul Karim, and A. Veloo, "Institutional support and e-learning acceptance: An extension of the technology acceptance model," Int. J. Instr. Technol. Distance Learn., vol. 8, no. 2, pp. 3-16, 2011.

[86] J. F. Hair, R. E. Anderson, B. J. Babin, and W. C. Black, Multivariate data analysis : a global perspective. Upper Saddle River, NJ: Pearson., 2010.

[87] M. Al-Emran and S. A. Salloum, "Students' Attitudes Towards the Use of Mobile Technologies in e-Evaluation," Int. J. Interact. Mob. Technol., vol. 11, no. 5, pp. 195-202, 2017. https://doi.org/10.3991/ijim.v11i5.6879

[88] C. M. Ringle, S. Wende, and A. Will, "SmartPLS 2.0 (Beta). Hamburg," Available in http://www. smartpls. de, 2005.

[89] W. W. Chin, "The partial least squares approach to structural equation modeling," Mod. methods Bus. Res., vol. 295, no. 2, pp. 295-336, 1998.

[90] J. C. Anderson and D. W. Gerbing, "Structural equation modeling in practice: A review and recommended two-step approach.," Psychol. Bull., vol. 103, no. 3, p. 411, 1988. https ://doi.org/10.1037/0033-2909.103.3.411

[91] J. F. Hair, W. C. Black, B. J. Babin, R. E. Anderson, and R. L. Tatham, Multivariate data analysis, vol. 5, no. 3. Prentice hall Upper Saddle River, NJ, 1998.

[92] D. Gefen, D. Straub, and M.-C. Boudreau, "Structural equation modeling and regression: Guidelines for research practice," Commun. Assoc. Inf. Syst., vol. 4, no. 1, p. 7, 2000. https://doi.org/10.17705/1 cais.00407

[93] J. C. Nunnally and I. H. Bernstein, "Psychometric theory," 1978.

[94] R. F. Falk and N. B. Miller, A primer for soft modeling. University of Akron Press, 1992. 
[95] C. Fornell and D. F. Larcker, "Evaluating structural equation models with unobservable variables and measurement error," J. Mark. Res., pp. 39-50, 1981. https://doi.org/10.1177/ 002224378101800104

[96] M. Alshurideh, S. A. Salloum, B. Al Kurdi, and M. Al-Emran, "Factors affecting the Social Networks Acceptance: An Empirical Study using PLS-SEM Approach," in 8th International Conference on Software and Computer Applications, 2019. https://doi.org/10.11 $\underline{45 / 3316615.3316720}$

[97] S. A. Salloum, A. Q. M. Alhamad, M. Al-Emran, A. A. Monem, and K. Shaalan, "Exploring Students' Acceptance of E-Learning Through the Development of a Comprehensive Technology Acceptance Model," IEEE Access, vol. 7, pp. 128445-128462, 2019. https://doi.org/10.1109/access.2019.2939467

[98] M. T. Alshurideh, S. A. Salloum, B. Al Kurdi, A. A. Monem, and K. Shaalan, "Understanding the Quality Determinants that Influence the Intention to Use the Mobile Learning Platforms: A Practical Study," Int. J. Interact. Mob. Technol., vol. 13, no. 11, pp. 157-183, 2019. https://doi.org/10.3991/ijim.v13i11.10300

[99] R. A. S. Al-Maroof and M. Al-Emran, "Students Acceptance of Google Classroom: An Exploratory Study using PLS-SEM Approach,” Int. J. Emerg. Technol. Learn., 2018. https ://doi.org/10.3991/ijet.v13i06.8275

[100] S. F. S. Alhashmi, S. A. Salloum, and S. Abdallah, "Critical Success Factors for Implementing Artificial Intelligence (AI) Projects in Dubai Government United Arab Emirates (UAE) Health Sector: Applying the Extended Technology Acceptance Model (TAM)," in International Conference on Advanced Intelligent Systems and Informatics, 2019, pp. 393405. https://doi.org/10.1007/978-3-030-31129-2_36

[101] S. A. Salloum and K. Shaalan, "Adoption of e-book for university students," in International Conference on Advanced Intelligent Systems and Informatics, 2018, pp. 481-494. https://doi.org/10.1007/978-3-319-99010-1 44

[102] S. A. Salloum and M. Al-Emran, "Factors affecting the adoption of E-payment systems by university students: Extending the TAM with trust," Int. J. Electron. Bus., vol. 14, no. 4, pp. 371-390, 2018. https://doi.org/10.1504/ijeb.2018.10019536

\section{Authors}

Barween Al Kurdi is an assistant Professor in Marketing and she is working for Amman Arab University - Faculty of Business - Marketing Department. She is a member of large number of committees and mainly the social committee. She used to publish in good ranked journals such as Journal of Marketing Communications and International Journal of Marketing Studies. You can contact D. Al Kurdi at balkurdi@aau.edu.jo.

Muhammad Alshurideh is working for Fujairah University in UAE as Dean of Faculty of Business and as fulltime lecturer for the University of Jordan. Regarding the teaching, he has the responsibilities to teach a wide range of marketing and business topics for both undergraduate and postgraduate students. The D. has more than 33 published papers in different marketing and business topics mainly CRM and Customer Retention areas. D. Alshurideh is used to publish in good ranked journals such as Journal of Marketing Communications and International Journal of Electronic Customer Relationship Management. You can contact D. Alshurideh via emails at: m.alshurideh@ju.edu.jo or m.shurideh@uof.ac.ae. 
Said A. Salloum had graduated from The British University in Dubai with a distinction with MSc in Informatics (Knowledge and Data Management). He got his Bachelor's degree in Computer Science from Yarmouk University. Currently, He is working at the University of Sharjah "Research Institute of Sciences and Engineering (RISE)" as a researcher on different research areas in Computer Science such as data analysis, machine learning, knowledge management, and Arabic Language Processing. Salloum is an Oracle expert since 2013 along with various recognized international certificates that are issued by Oracle.

Dr Zaid Obeidat holds a PhD in Marketing from Durham University, an MBA and a BA in Marketing. Zaid is currently an assistant professor in marketing in the University of Jordan. His work focuses on consumer rights, consumer behavior, misbehavior, and the online context. His main interest lies in consumer online revenge behaviors and the variables that affect and encourages these behaviors. He works in the university of Jordan teaching International marketing, consumer behavior, and marketing management \& research. His work has been published in Many well respected International Journals \& conferences such as Psychology and Marketing, Journal of Retailing and Consumer services, IJBR, EJBR, and EMAC.

Dr Rami Aldweeri is an assistant professor in Business school at the University of Jordan, Rami completed his $\mathrm{PhD}$ and Master in Marketing at Malaga University, and his undergraduate studies at Yarmouk University. His research interest lies in the area of digital marketing especially in e-service quality, e-loyalty, e-trust. Rami's work was published in international Journal such as Total Quality Management and Business Excellence, Computers in Human Behavior, International Journal of Marketing Studies and Universia Business Review.

Article submitted 2019-06-25. Resubmitted 2019-12-05. Final acceptance 2019-12-06. Final version published as submitted by the authors. 